\title{
Dantrolene for the treatment of MDMA toxicity
}

\author{
Brian E. Grunau, MD; ${ }^{*}$ Matthew O. Wiens, PharmD; ${ }^{\dagger}$ Marc Greidanus, $\mathrm{MD}^{\ddagger}$
}

See related article on page 435

\begin{abstract}
MDMA (3,4-methylenedioxymethamphetamine), popularly known as "Ecstasy," was first introduced and patented by Merck \& Co., Inc., in 1914 as an appetite suppressant. Currently, its primary role is as an illegal stimulant used to produce a euphoric effect during parties. This case report describes a 31-year-old man who, after taking 3 tablets of Ecstasy, presented to an emergency department with a decreased level of consciousness and became progressively hyperthermic and rigid. During the course of his acute illness, his temperature reached $42.2^{\circ} \mathrm{C}$ rectally. He was given mechanical ventilation. He was aggressively cooled and dantrolene was initiated. Soon after the administration of dantrolene his temperature decreased and his rigidity began to resolve. The only complication was rhabdomyolysis with a creatine kinase level increasing to over $150 \mu \mathrm{kat} / \mathrm{L}$. This did not progress to acute renal failure. The patient made a full recovery and was discharged to psychiatry for assessment.
\end{abstract}

Keywords: MDMA, toxicology, dantrolene, MDMA-related hyperpyrexia

\section{RÉSUMÉ}

La MDMA (3,4-méthylènedioxyméthamphétamine), mieux connue sous le nom d'ecstasy, a été introduite et brevetée par Merck \& Co. Inc., en 1914 comme anorexigène. Actuellement, elle est principalement utilisée comme stimulant illégal qui produit un effet euphorique. Nous présentons le cas d'un homme de 31 ans qui s'est présenté à l'urgence avec un état de conscience modifié, après avoir pris 3 comprimés d'ecstasy. II est devenu progressivement hyperthermique et rigide. Pendant la phase aiguë de sa réaction, sa température rectale a atteint $42,2^{\circ} \mathrm{C}$. On a utilisé une ventilation assistée, eu recours au refroidissement et administré du dantrolène. Peu de temps après l'administration de dantrolène, sa température a baissé et sa rigidité a commencé à se résorber. La seule complication a été une rhabdomyolyse avec un taux élevé de créatine kinase, à plus de $150 \mu$ kat/L. Son état n'a pas évolué vers l'insuffisance rénale aiguë. Le patient s'est complètement rétabli et a été transféré en psychiatrie aux fins d'évaluation.

\section{INTRODUCTION}

Although originally patented as an appetite suppressant $t^{1}$ and later used in psychotherapy, MDMA (3,4-methylenedioxymethamphetamine) is currently referred to as "Ecstasy," "E" or "X" in its current niche as a recreational street drug. Use of MDMA has become very prevalent since the 1970s, in part because of its reputation as a "safe" euphoric agent. Lifetime use in Canada for those over 15 years old was reported in 2004 as $3.0 \%$ and $5.2 \%$ for women and men, respectively, ${ }^{2}$ and in the United States was reported at $5.8 \%$ in grade $9-12$ students. ${ }^{3}$ In spite of its high prevalence, relatively few people experience adverse effects. The reason for this and the seemingly random occurrence of toxicity among users is unknown. The fatality rate from MDMA for people aged 15-24 years in the United Kingdom has been estimated to be $0.002 \%-0.053 \%$ of users. ${ }^{4}$ We report a case of MDMA intoxication resulting in extreme hyperpyrexia, which responded to treatment with dantrolene.

\section{CASE REPORT}

At approximately 9:30 pm a 31-year-old man with a decreased level of consciousness presented via paramedics to the emergency department of a small 100-bed rural hospital. Police had found the man outside lying on the ground. In the ambulance, vitals were as follows: heart rate 150 beats/min, blood pressure 150/100 $\mathrm{mm} \mathrm{Hg}$,

From the *Department of Emergency Medicine, St. Paul's Hospital and the University of British Columbia, Vancouver, BC, the †Department of Pharmacy, Chilliwack General Hospital, Chilliwack, BC, as well as the School of Population and Public Health, University of British Columbia, Vancouver, BC, and the ¥Department of Emergency Medicine, Chilliwack General Hospital, Chilliwack, BC

Submitted Jul. 23, 2009; Revised Nov. 23, 2009; Dec. 4, 2009

This article has been peer reviewed.

CJEM 2010;12(5):457-9 
temperature $36.2^{\circ} \mathrm{C}$. The patient was tremulous, pupils were equal and the skin appeared normal.

Initial assessment by the nurse revealed the following: heart rate 162 beats/min, blood pressure 135/72 $\mathrm{mm} \mathrm{Hg}$, respiratory rate 24 breaths/min, oxygen saturation $97 \%$ (room air), temperature $38.1^{\circ} \mathrm{C}$ (axillary) and Glasgow Coma Scale score 13. The patient appeared diaphoretic and flushed, and exhibited a mild general tremor. Although the patient had difficulty focusing on questions asked, he was easily redirected and was oriented to time and place.

On assessment by the physician at 10:30 pm the patient's blood pressure was $142 / 90 \mathrm{~mm} \mathrm{Hg}$ with a heart rate of 172 beats/min and an unchanged temperature. The patient appeared very restless, with marked shivering and diaphoresis. Mental status examination revealed disorganized thinking, easy distractibility, mild agitation and disorientation to time. Laboratory tests were ordered and treatment with intravenous lorazepam was commenced.

Reassessment at 11:30 pm showed the patient in a tachypneic state with a respiratory rate reported on the nursing assessment as 54 breaths/min and an oxygen saturation of $97 \%$ on $10 \mathrm{~L} / \mathrm{min}$ of oxygen via face mask. His admission electrolyte levels were within normal limits. The patient had become progressively more hyperthermic with a temperature of $39.8^{\circ} \mathrm{C}$ (axillary). Pupils were dilated to $5 \mathrm{~mm}$ and nonresponsive. The patient was now delirious and acutely psychotic. He was no longer oriented to person or place and demonstrated pressured speech and a complete loosening of associations with disorganized thought. Physical examination revealed extreme diaphoresis with shivering, loud heart sounds, generalized muscle rigidity and a tense abdomen. Cold saline bags were placed on his groin and axilla. Normal saline boluses were given to maintain urine output above $60 \mathrm{~mL} / \mathrm{min}$.

Between 10:15 and 11:31 pm a total of $10 \mathrm{mg}$ of intravenous lorazepam had been given with little effect except possibly contributing to the decreased level of consciousness. Additionally, $6 \mathrm{~L}$ of room temperature normal saline were given between 11:30 pm and 12:18 am to maintain adequate urine output.

At midnight the patient's temperature (rectal) was recorded as $42.2^{\circ} \mathrm{C}$ (Fig. 1). The patient was rigid. Active treatment for hyperpyrexia was initiated with a cooling blanket. Laboratory testing revealed a leukocytosis (white blood cell count $34.6 \times 10^{9} / \mathrm{L}$ ) with left shift, an elevated platelet count $\left(464 \times 10^{9} / \mathrm{L}\right)$, and a creatine kinase value of $5.86 \mu \mathrm{kat} / \mathrm{L}$ (increased to $161.82 \mu \mathrm{kat} / \mathrm{L}$ in follow-up blood testing at 11:10 pm).
At 12:31 am the patient was sedated with a midazolam and morphine infusion and was treated with mechanical ventilation for protection of his airway. At 1:17 am his temperature had decreased to $39.4^{\circ} \mathrm{C}$ (rectal) with active cooling. Dantrolene $80 \mathrm{mg}$ was given intravenously. Thirteen minutes later his temperature had decreased to $38.2^{\circ} \mathrm{C}$ (rectal). After a further 37 minutes the temperature was $37.7^{\circ} \mathrm{C}$ (rectal). At $2: 30 \mathrm{am}$, approximately 73 minutes after dantrolene was given, his temperature had decreased to $37.1^{\circ} \mathrm{C}$ (oral) and remained below this for the duration of the night.

Urine toxicology testing was positive for amphetamines, cannabinoids and lithium. Acetylsalicylic acid was not detected. His serum lithium level was normal at $0.2 \mathrm{mmol} / \mathrm{L}$ (therapeutic range $0.6-0.8 \mathrm{mmol} / \mathrm{L}$ ). The patient's medical history included bipolar disorder for which he had previously been treated with olanzapine. However, at the time of illness the patient had not received olanzapine for several months. At the time of presentation, he was taking only lithium and valproic acid. The patient's tube was removed after 36 hours, and he was later discharged with no further complications.

\section{DISCUSSION}

In spite of the low incidence of adverse effects secondary to use of MDMA, it does have the potential to cause severe complications, including extreme hyperpyrexia, rhabdomyolysis, acute kidney injury, hepatotoxicity, coagulopathy, metabolic acidosis, seizures, cerebral and cardiac ischemia, cerebral edema, electrolyte abnormalities, arrhythmias, shock requiring treatment in the intensive care unit and death. The treatment of MDMA-related hyperpyrexic syndrome should be primarily supportive and has been well described previously. ${ }^{5}$ It is thought that this entity is a form of serotonin syndrome, ${ }^{6}$ primarily invoking

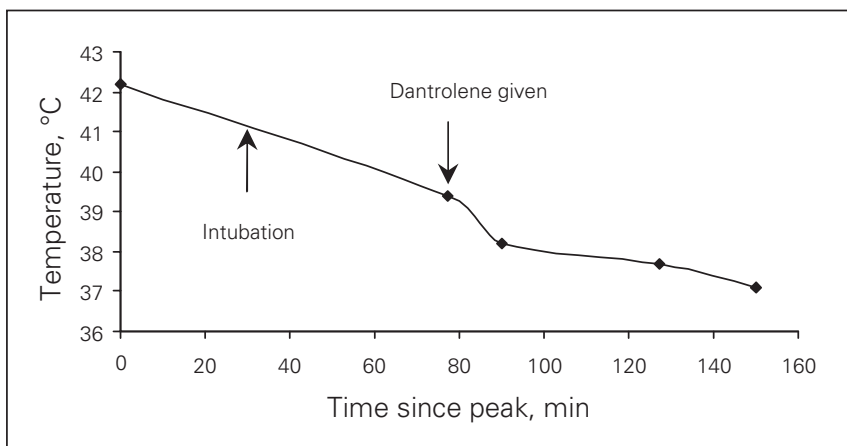

Fig. 1. Temperature (rectal) of a 31-year-old man with MDMA toxicity, by time after peak temperature. 
blockade of serotonin reuptake and, to a lesser extent, involving dopamine and norepinephrine. ${ }^{7}$ With no dose-response relationship between MDMA ingestion and toxicity and no known triggers, the mechanism of MDMA hyperpyrexial toxicity remains elusive. Several theories have been suggested including a connection with malignant hyperpyrexia, ${ }^{8}$ which led to the use of dantrolene in MDMA-induced hyperpyrexia. The first successful documented use of dantrolene in Ecstasy toxicity was in $1992^{\circ}$ and has prompted numerous case reports since, although controversy regarding its use continues. ${ }^{10}$

Although proof of causality can be reliably attained only through the use of randomized controlled trials, we believe that cases such as this continue to provide an indication that dantrolene may be effective in the treatment of hyperpyrexia secondary to MDMA toxicity. We acknowledge the significant limitations of multimodal treatment in this case, including cooling blankets and paralysis for intubation. However, the time-temperature relation line in this patient clearly displays a sharper slope after treatment with dantrolene. Unfortunately, our limited temperature data cannot accurately assess when the temperature began to decline. It is worth noting that irrespective of its effect on temperature, dantrolene was associated with a good outcome in this patient. In a concurrently published systematic review of dantrolene-associated hyperpyrexia, it was found that in the 13 patients who had a temperature of greater than $42^{\circ} \mathrm{C}$ who received dantrolene, there were 8 survivors $(62 \%)$. In the 4 patients with a temperature of greater than $42^{\circ} \mathrm{C}$ who did not receive dantrolene, none survived. ${ }^{11}$ We acknowledge the potential of publication bias in this claim.

We believe our case gives further support that dantrolene may be clinically effective in the treatment of MDMA toxicity by its association with temperature reduction and a favourable clinical outcome. Although a true randomized controlled trial would be difficult to stage, further research is required to confirm the causality of this agent in the treatment of MDMA toxicity.
Competing interests: None declared.

\section{REFERENCES}

1. Merck E, inventor. Varfeharen Zur Darstellung Von Alkyloxyaryl-Dialyoxyaryl-Und Alkylenedioxyarylaminopropanen Bzw. Deren Am Stickstoff Monoalkylierten. German patent 274350. 1914

2. Adlaf EM, Begin P, Sawka E. Canadian Addiction Survey (CAS): a national survey of Canadians' use of alcobol and other drugs: prevalence of use and related harms, detailed report. Ottawa (ON): Canadian Centre on Substance Abuse (CCSA); 2005.

3. Eaton DK, Kann L, Kinchen S, et al. Youth risk behavior surveillance - United States, 2007. MMWR Surveill Summ 2008;57:1-131.

4. Gore SM. Fatal uncertainty: death-rate from use of ecstasy or heroin. Lancet 1999;354:1265-6.

5. Hall AP, Henry JA. Acute toxic effects of "ecstacy" (MDMA) and related compounds: overview of pathophysiology and clinical management. Br J Anaesth 2006;96:678-85.

6. Boyer EW, Shannon M. The serotonin syndrome. $N$ Engl J Med 2005;352:1112-20.

7. Kalant H. The pharmacology and toxicology of "ecstasy" (MDMA) and related drugs. CMAJ 2001;165:917-28.

8. Larner AJ. Dantrolene and "ecstasy" overdose. Anaesthesia 1993;48:179-80.

9. Singarajah C, Lavies NG. An overdose of ecstasy. A role for dantrolene. Anaesthesia 1992;47:686-7.

10. Duffy MR, Ferguson C. Role of dantrolene in treatment of heat stroke associated with ecstasy ingestion. Br 7 Anaesth 2007;98:148-9.

11. Grunau BE, Wiens MO, Brubacher JR. Dantrolene in the treatment of MDMA-related hyperpyrexia: a systematic review. CJEM 2010;12:435-42.

Correspondence to: Dr. Matthew Wiens, 45600 Menholm Rd., Department of Pharmacy, Chilliwack General Hospital, Chilliwack BC V2P 1P7; matthew.wiens@fraserhealth.ca 